\title{
The Dialectics of Remembrance: Memories of Empire in Cold War Japan
}

\author{
SEBASTIAN CONRAD
}

\author{
Freie Universität Berlin
}

In the half-century beginning in 1895, Japan had assembled one of the largest empires in modern history. This empire vanished in the summer of 1945, at the end of the Second World War, and it seemed to fall into immediate oblivion. Most commentators since have described Japan's postwar decades as characterized by a conspicuous absence of the country's imperial past in public debates and political culture. "The Japanese empire," declared Ian Nish in 1980, "disappeared without trace." 1 According to this standard view, references to the former colonial territories virtually disappeared, and almost instantaneously at that, when empire ended. Although some imperial structures continued to exist, many of these continuities were rendered invisible under the postwar memory regime of the victimized nation. Japan's wartime engagement in East Asia, and its longer colonialist record in the region, remained on the sidelines of larger social issues and conflicts. The philosopher and cultural critic Karatani Kōjin has spoken of the "De-Asianization" of postwar discourse in Japan as a general characteristic of the political and intellectual landscape in the years of the economic miracle. ${ }^{2}$

The disappearance of the country's imperial past has sometimes been perceived as specifically Japanese, and in some ways as a continuation of an earlier, nineteenth-century strategy to "leave Asia" (datsu-a). In fact, however, such a narrative was not at all singular or unique, and it had many

Acknowledgments: For comments, I am grateful to Nadin Heé, Christoph Kalter, Franziska Seraphim, Stefan Tanaka, Julia Adeney Thomas, and the anonymous CSSH reviewers. My thanks also go to Mizutani Satoshi and Tobe Hideaki for valuable suggestions and references, to Stuart Ward for the original suggestion that I write this article, and to David Akin for his careful editing. All translations from Japanese sources are my own, unless otherwise stated. This work was supported by the Academy of Korean Studies (KSPS) Grant funded by the Korean Government (MOE) (AKS-2010-DZZ-3103).

1 Ian Nish, "Regaining Confidence: Japan after the Loss of Empire," Journal of Contemporary History 15 (1980): 181-95, here 194.

2 Karatani Kōjin, "The Discursive Space of Modern Japan," in Masao Miyoshi and Harry D. Harootunian, eds., Japan in the World (Durham: Duke University Press, 1993). A similar point was made by Yoon Keun-cha, in Nihon kokuminron: kindai Nihon no aidentiti (Tokyo: Chikuma shobō, 1997). 
parallels in other countries. For instance in Germany, like Japan defeated in World War II, the imperial past - both overseas and in the European Eastwas largely eclipsed in the wake of defeat and the need to come to terms with the fascist past. ${ }^{3}$ And even countries that lost their empire only as a result of the postwar decolonization process, such as France or Great Britain, were quick to forget about their imperial engagements. "The British Empire may (or may not) have been won in a fit of 'absence of mind,"' as David Cannadine opined, "but as far as the majority of the population was concerned it was given away in a fit of collective indifference." 4 And Bernard Porter, in The Absent-Minded Imperialists, concluded, "domestic issues were separate, and of far more significance to most people on every level than almost any concerning the empire." 5 Likewise in France, the long colonial history, and the bloody and violent Algerian war in particular, were lost sight of soon after the treaty of Evian. ${ }^{6}$

For a long time, the "minimal impact thesis" - according to which the end of empire had virtually no reverberations in the metropoles - was the dominant reading of the decolonization process. ${ }^{7}$ In recent years, though, scholarship on postwar Europe has modified and for some parts corrected this familiar and widespread picture of imperial amnesia, and has demonstrated the extent to which effects of the expansionist past did indeed penetrate deep into former imperial societies. This discussion is still in full swing, and in some cases the scholarly literature is still in its infant stage. What has begun to emerge, however, is a more nuanced picture. Once we leave the realm of diplomacy and high politics, we find that the trope of imperial erasure is overly simplistic. In most countries, albeit in a variety of very different ways, former empires remained present in segments of popular culture, and through the effects of postcolonial migration that had a profound impact on social conflicts and debates about national identities. ${ }^{8}$

3 For a recent overview, see Michel Perraudin and Jürgen Zimmerer, eds., German Colonialism and National Identity (London: Routledge, 2010).

4 David Cannadine, "Apocalypse When? British Politicians and British 'Decline' in the Twentieth Century," in Peter Clarke and Clive Trebilcock, eds., Understanding Decline: Perceptions and Realities of British Economic Performance (Cambridge: Cambridge University Press, 1997), 261-62.

5 Andrew Porter, The Absent-Minded Imperialists: What the British Really Thought about Empire (Oxford: Oxford University Press, 2004), 269.

6 Benjamin Stora, La Gangrène et l'oubli: la mémoire de la guerre d'Algérie (Paris: Editions La Découverte, 1991).

7 This term was coined by Stuart Ward, in "Echoes of Empire," History Workshop Journal 62 (2006): 264-78, quote 266.

8 See Stuart Ward, ed., British Culture and the End of Empire (Manchester: Manchester University Press, 2001); Wendy Webster, Englishness and Empire 1939-1965 (Oxford: Oxford University Press, 2005); Catherine Hall and Sonya O. Rose, eds., At Home with the Empire: Metropolitan Culture and the Imperial World (Cambridge: Cambridge University Press, 2006); Catherine Coquery-Vidrovitch, Enjeux politiques de l'histoire coloniale (Paris: Agone, 2009); Todd Shepard, The Invention of Decolonization: The Algerian War and the Remaking of France 
Against this backdrop, it is worth asking to what extent these insights may also be applied to the Japanese case. In recent years, a renewed interest in Japan's imperial past has spawned a number of studies that have contributed to a more complex picture of the dialectic between forgetting and remembering. They have focused on a wide variety of actors and have demonstrated how dynamics have shifted over time. The result is not a plain reversal of the imperial erasure thesis; on the contrary, recent studies have underscored the mechanisms that have helped to marginalize memories of empire in the years of high growth. But they have specified much more precisely the conditions under which imperial continuities were at work, and how fictions of a clean slate were able to emerge.

In this essay, I will draw on recent scholarship to arrive at a comprehensive interpretation of the trajectories of memories of empire throughout Japan's postwar period. The argument will come in four parts. After a brief assessment of the significance of Japan's imperial possessions up until its surrender in 1945, I will first relate the dominant view that Japan's postwar period was characterized by a fundamental erasure of the imperial past. While this reading continues to have considerable analytical traction, I will then show that it is one-sided and tends to erase, in its own way, a series of engagements with imperial legacies, by a variety of actors, in the immediate postwar period and also, albeit to a lesser degree, after 1960. Third, the dialectic of remembering and forgetting needs to be understood within the context of the global Cold War and its East Asian ramifications. And finally, I will examine how the demise of the bipolar world order in the 1990s effectuated a resurgent interest in Japan's Asian past, albeit in a new guise. Put generally, this article will argue that the history of imperial memory was not a Japanese affair alone, but must be situated within larger processes and transformations of the postwar order in East Asia.

JAPAN'S EMPIRES AND IMPERIAL JAPAN

Assembled between 1895 and 1945, Japan's modern empire was one of the largest imperial structures in the modern history of colonialism. It was an empire acquired in several steps, and made up of different kinds of territories. The annexations of Taiwan in 1895 and Korea in 1910 were part and parcel of the era of high imperialism inaugurated by the scrambles for Africa in the 1880 s, and for China in the late 1890s. Synchronous with many European powers, and after 1898 the United States as well, Japan enlarged her sphere

\footnotetext{
(Ithaca: Cornell University Press, 2006); Margarida Calafate Ribeiro and Ana Paula Ferreira, Fantasmas e Fantasias Imperiais no Imaginário Português Contemporâneo (Porto: Campo das Letras, 2003); Jacqueline Andall and Derek Duncan, eds., Italian Colonialism: Legacy and Memory (Oxford: Peter Lang Publishing, 2005); Wim Willems, De uittocht uit Indië: De geschiedenis van Indische Nederlanders, 1945-1995 (Amsterdam: Bert Bakker, 2001).
} 
of influence and secured a crucial resource base to be exploited by the metropole. This empire was further enlarged when after the First World War parts of the German possessions in the Pacific fell to Japan under the mandate system of the League of Nations. In the interwar years, the colonial territories, most notably Taiwan and Korea, were further integrated into the Japanese Empire by a politics of cultural assimilation $(d \bar{o} \mathrm{ka}$ ) that treated the colonized populations as legally Japanese. ${ }^{9}$ In many ways differences remained, and assimilation did not preclude discrimination in such things as education, wage levels, and access to offices and the censored public sphere. But ideologically the colonies were treated within Japanese discourse as part of the nation, culminating in provisions for linguistic homogenization and forced name changes in Korea in the early 1940 s. $^{10}$

The so-called puppet regime of Manchukuo, inaugurated in 1932, was legally not a colony but an autonomous state. Formally headed by Qing China's "last emperor" Pu Yi (now Kangde), it was a colony dressed up as a state but effectively under the command of the Japanese army. Manchukuo was not merely a continuation of Meiji Japan's imperialism, however. Instead, it was ruled as a modern developmental state and was an example of what Prasenjit Duara has called the "imperialism of "free nations," a new form of empire building that foreshadowed the rise of vassal states in the postwar period. The ideology of rule was inflected by the strong Pan-Asian currents of the interwar period. Moreover, Japan invested heavily in the region's industrial development, turning Manchukuo into the most industrialized part of all of Asia outside Japan. Japan invested more heavily in its colonies than did any other empire. The developmentalist approach did not eliminate hierarchies, and Japanese rule remained characterized by exploitation and brutal suppression of dissent. But with their emphasis on anti-colonial ideology, economic investments, and legal sovereignty, and a stress on cultural similarities, the Japanese intended Manchukuo to form a regional block with Japan. In this way, it represented a departure from the nineteenth-century tradition of imperialism. ${ }^{11}$

${ }^{9}$ On the different phases of Japan's assimilation politics, see Leo T. S. Ching, Becoming 'Japanese': Colonial Taiwan and the Politics of Identity Formation (Berkeley: University of California Press, 2001).

${ }^{10}$ For overviews of the Japanese colonial empire, see W. G. Beasley, Japanese Imperialism 1894-1945 (Oxford: Oxford University Press, 1987); Mark Peattie and Ramon H. Myers, eds., The Japanese Colonial Empire 1895-1945 (Princeton: Princeton University Press, 1984); Peter Duus and Mark Peattie, eds., The Japanese Informal Empire in China, 1895-1937 (Princeton: Princeton University Press, 1991); Peter Duus, ed., The Japanese Wartime Empire, 1931-1945 (Princeton: Princeton University Press, 1996). See also Iwanami Kōza, Kindai Nihon to shokuminchi, 8 vols. (Tokyo: Iwanami Shoten, 1992-1993).

${ }^{11}$ See Prasenjit Duara, Sovereignty and Authenticity: Manchukuo and the East Asian Modern (Lanham: Rowman \& Littlefield, 2003). On Manchukuo, see also Yoshihisa Tak Matsusaka, The Making of Japanese Manchuria, 1904-1932 (Cambridge: Harvard University Press, 2001); 
Beginning with the war on the Chinese mainland in 1937, the Japanese Empire was further extended to include large parts of China, and subsequently of Southeast Asia. As is suggested by the official label of the "Greater East Asian War" and the politico-economic goal of creating a "Greater East Asian Co-Prosperity Sphere," territorial expansion was accompanied by a rhetoric of Asian liberation and anti-imperialism. ${ }^{12}$ In 1942, at the moment of its greatest extension, the empire encompassed territories spanning over 7,400,000 square kilometers. Apart from its impressive size, the Japanese Empire was peculiar both in the degree of control to which it subjected the colonized territories and populations, and in the way the colonized territories were closely linked to and exploited by the Japanese archipelago. Japan treated its colonies not as distant overseas possessions but rather as parts of a hierarchical and differentiated, but economically and ideologically integrated imperial structure. ${ }^{13}$

Japan's empire was thus a large and variegated entity, closely linked to Japan's rise as a major world power. But the empire's importance was not limited to Japan's international status, foreign policy, and quest for economic autarchy. It is essential to recognize that the empire was not only a manifestation of Japanese power projected abroad, but was also intimately connected with the domestic process of Japan's modernization. From early on, the Meiji modernization efforts were linked to expansionist projects overseas. Among the overriding objectives of the Meiji elite was to reverse Japan's subordinated integration into the international order, and to achieve abolition of the so-called "unequal treaties" concluded with global powers in the 1850 s. Under the premises of international law, the achievement of full sovereignty was conditioned upon Japan's status as a "civilized nation," and the Meiji oligarchy saw the ability to conquer and civilize others as a shortcut to treaty revision. Political modernization and imperial expansion were thus not consecutive stages, but rather mutually constitutive and synchronous. ${ }^{14}$

Sandra Wilson, The Manchurian Crisis and Japanese Society, 1931-1933 (London: Routledge, 2001).

${ }^{12}$ See Tetsuo Najita and Harry. D. Harootunian, "Japanese Revolt against the West: Political and Cultural Criticism in the Twentieth Century," in Peter Duus, ed., The Cambridge History of Japan, Vol. 6: The Twentieth Century (Cambridge: Cambridge University Press, 1989); Harry D. Harootunian, Overcome by Modernity: History, Culture, and Community in Interwar Japan (Princeton: Princeton University Press, 2000); Richard F. Calichman, ed., Overcoming Modernity: Cultural Identity in Wartime Japan (New York: Columbia University Press, 2008).

13 According to official Japanese taxonomy, all territories acquired after 1889 (the promulgation of the Meiji constitution) were considered colonies: Taiwan, Karafuto, Korea, and Nanyō. This excluded an important dimension of Japanese empire building, namely internal colonialism in Hokkaido and Okinawa ("internal" because these territories were incorporated into the Japanese nationstate as naichi, internal territories), as well as Manchukuo, which was formally not a colony but an autonomous state.

${ }^{14}$ See the argument by Robert Eskildsen, "Of Civilization and Savages: The Mimetic Imperialism of Japan's 1874 Expedition to Taiwan," American Historical Review 107 (2002): 388-418. See 
This logic did not change after the consolidation of a territorial empire. In their impact, interventions were never simply confined to the colonies, but always had repercussions on the Japanese archipelago. ${ }^{15}$ Goto Shimpei (1857-1929), the empire's chief architect, treated Taiwan as a sort of laboratory where technologies of modernization - ranging from urban planning to sanitary measures and the politics of hygiene - could be tested before being applied to the metropole, most notably in the reconstruction of Tokyo after the earthquake of 1923. ${ }^{16}$ The most important testing ground, however, was Manchukuo. Louise Young has demonstrated how Manchuria was turned into a laboratory for what the "new bureaucrats" of the Shōwa period envisioned as Japanese modernity. The new capital, Xinjing, was developed as a model city with geometrical structure, green spaces, and parks, with a sanitary infrastructure and modern sewage system long before these technologies became standard in Japan. Beyond city planning, reformers fused Soviet models of a planned economy with the Pan-Asian discourse of autarchic production and the forms of total wartime mobilization in order to test economic theories before applying them to Japan. ${ }^{17}$ The bottom line of this recent scholarship is very clear: Japan's empire was never just "out there"; it was closely linked to the metropole, beyond the more than 320,000 Japanese settlers who had migrated to Manchuria. The empire was, quite literally, an inextricable ingredient of imperial Japan.

\section{NARRATIVES OF INSTANT DECOLONIZATION}

This large and far-flung empire rapidly came undone in the summer of 1945. Unconditional surrender not only brought the hostilities of World War II to a close, but also marked the end of Japan's overseas possessions. To many contemporaries, this shift seemed almost instantaneous. Emperor Hirohito's surrender speech of 15 August 1945-more than the official capitulation on 2 September-burned itself into the memories of large parts of the Japanese population. In general parlance, this "zero hour" divided the prewar (senzen) from the postwar (sengo), and imperial from occupation, and then high-growth

also Andre Schmid, "Colonialism and the 'Korea Problem' in the Historiography of Modern Japan, A Review Article," Journal of Asian Studies 59 (2000): 951-76.

15 This argument has been made most forcefully by scholars in the field of postcolonial studies. See, for example, Kang Sang-jung, Orientarizumu no kanata e: Kindai bunka hihan (Tokyo: Iwanami Shoten, 1996); Komagome Takeshi, Shokuminchi teikoku Nihon no bunka tōgō (Tokyo: Iwanami Shoten, 1996); Tomiyama Ichirō, Kindai Nihon shakai to 'Okinawajin': "Nihonjin” ni naru to iu koto (Tokyo: Nihon Keizai Hyōronsha, 1990); Stefan Tanaka, Japan's Orient: Rendering Pasts into History (Berkeley: University of California Press, 1993).

16 Hashiya Hiroshi, Teikoku Nihon to shokuminchi toshi (Tokyo: Yoshikawa Kōbunkan, 2004).

17 Louise Young, Japan's Total Empire: Manchuria and the Culture of Wartime Imperialism (Berkeley: University of California Press, 1998). On city planning, see also Koshizawa Akira, Manshūkoku no shuto keikaku: Tōkyō no genzai to mirai o tou (Tokyo: Chikuma Shobō, 1988). 
Japan. The notion of an absolute discontinuity across the 1945 divide became one of the foundational myths for the new and reborn Japan (shinsei Nippon). ${ }^{18}$

Along similar lines, historians have tended to narrate the fate of Japan's empire as a story of what could be called "instant decolonization." According to this dominant view, the empire disappeared all of a sudden and left hardly a trace. The redrawing of boundaries in East Asia had been part of Allied wartime planning and received sanction at the conferences at Yalta and Potsdam. With unconditional surrender, the colonized territories were severed from a Japan now confined to the four islands of the archipelago: The "island nation" (shimaguni) was born, self-sufficient and inward looking. Consequently, to many Japanese the colonial possessions appeared not as liberated or gradually ceded but rather, as simply gone. As a result, "Japan's empire was terminated with little discussion." 19

This view is typically linked to an argument according to which Japan did not experience the pangs and conflicts of the drawn out and frequently violent processes of imperial devolution suffered by other global powers. The Japanese Empire, states Leo Ching, "has liquidated itself without going through the process of decolonization." ${ }^{20}$ In this line of reasoning, there was no parallel in East Asia to the decade-long fights with the Algerian National Front that brought France to the verge of a coup d'état and led to bloodshed, torture, and massacre, even in Paris, to the Mau Mau war, or to the painful retreat of British settlers from Kenya and Rhodesia. This is, of course, only partially true, since there was strong and violent local resistance to Japanese rule in the years before 1945, driven by a variety of local groups, many of which fought in the name of national liberation. In many ways, the military conflict in China, as well as the forays of different Korean groups based in Manchuria, Shanghai, and Korea itself should be seen as parts of decolonization struggles, and the same can be said of the war against Japan in Southeast Asia. But while these conflicts are remembered in many Asian societies as steps toward national liberation and decolonization, in Japan they were perceived primarily as concomitants of world war. Therefore, the loss of empire was understood by many as a form of immediate decolonization effected largely by external forces, what Lori Watt has called "third-party-decolonization." "21 The former empire, therefore, "was never of domestic concern; it was the problem of other nations." 22

${ }^{18}$ Carol Gluck, "The 'End' of the Postwar: Japan at the Turn of the Millennium," Public Culture 10 (1997): 1-23.

${ }_{19}$ Lori Watt, When Empire Comes Home: Repatriation and Reintegration in Postwar Japan (Cambridge: Harvard University Press, 2009), 3.

${ }^{20}$ Leo Ching, “'Give Me Japan and Nothing Else!': Postcoloniality, Identity, and the Traces of Colonialism," in Tomiko Yoda and Harry Harootunian, eds., Japan after Japan: Social and Cultural Life from the Recessionary 1990s to the Present (Durham: Duke University Press, 2006), 148.

21 Watt, When Empire Comes Home.

${ }^{22}$ Ching, “'Give Me Japan'," 148. For a similar reading, see Tomiyama Ichirō, Sensō no kioku (Tokyo: Nihon Keizai Hyōronsha, 1995), 108-12. 
This paradigm of instant disappearance is not a simple projection by historians; it was supported by a reconfiguration of postwar Japan, under conditions of the U.S. occupation, that was conducive to a vision of the past, and future, that extracted Japan from its regional contexts. On the most general level, this found expression in a rhetoric that simply avoided imperial references. "Our nation, pressed back to the small Japan at the time of the Meiji Restoration, should draw lessons for the future from past mistakes, turn over a new page and immediately start to build a new Japan," declared Prince Higashikuni, the transitional prime minister after surrender in $1945 .^{23}$ This new Japan was to be small, and thus non-imperial, and it was to move its orientation away from Asia and toward the West. The renowned social scientist Maruyama Masao famously called for a "third opening of the country" (kaikoku). ${ }^{24}$

Under the conditions of the American military presence, the new constitution, and economic recovery, the Japanese government firmly pursued a policy of alignment with the West. The seven-year U.S. occupation helped reformat public life, the political order, and the sense many Japanese had of their place in the world. Even after the occupation ended, the security treaties tied Japan to the overall military strategy of the United States. Economically, the close links with the occupying power guaranteed virtually unrestricted access to Western markets, especially in the United States. At the same time, Asia's relevance as an economic partner was in steep decline. ${ }^{25}$ Waves of Americanization affected consumer demand, everyday life, and popular culture, and facilitated a turn away from Japan's imperial hinterland. The result was a Japan that was again poised to "leave Asia and join the West," as Fukuzawa Yukichi had postulated in $1885 .^{26}$

This was especially apparent in the way in which the imperial context was expunged from narratives of Japan's modern history. In this process the U.S. occupation played a crucial role. It contributed to casting the history of war and fascism essentially in domestic terms, as a war that was caused primarily by internal factors and could thus be addressed by measures of social reform. A good example of this domestication of the past was the Tokyo War Crimes Trial. As suggested by the official wording of the indictment, the trial dealt

23 Quoted in Asano Toyomi, Teikoku Nihon no shokuminchi hōsei (Nagoya: Nagoya Daigaku Shuppankai, 2008), 571.

24 Maruyama Masao, "Kaikoku," in Maruyama Masao Shū, vol. 8 (Tōkyō: Iwanami Shoten, 1996), 45-86.

25 See Aaron Forsberg, America and the Japanese Miracle: The Cold War Context of Japan's Postwar Economic Revival, 1950-1960 (Chapel Hill: University of North Carolina Press, 2000).

${ }^{26}$ On the presence of the United States in Japan, see: John Dower, Embracing Defeat: Japan in the Wake of World War II (New York: Norton, 1999); Yoshimi Shun'ya, “'America' as Desire and Violence: Americanization in Postwar Japan and Asia during the Cold War," in Kuan-Hsing Chen and Beng Hua Chua, eds., Inter Asia Cultural Studies Reader (London: Routledge 2007), 246-66; Michael Auslin, Pacific Cosmopolitans: A Cultural History of U.S. - Japan Relations (Cambridge: Harvard University Press 2011). 
with a war whose causes lay at home and could thus be understood and remedied internally: "It is necessary to consider in the first place the domestic history of Japan during the same period.... Indeed the answers to the questions 'Why did these things happen?' and 'Who were responsible for their occurrence?' will often only be found if the contemporaneous history of Japanese domestic politics is known." 27

Fifteen years of war on the Asian mainland and the complicated international context of Japan's expansionist politics notwithstanding, the occupation authorities chose to relegate the imperial context to the fringes of Japan's history. It was no accident, then, that many significant crimes and atrocities committed by Japan in its Asian empire played only a marginal role in the trial proceedings. "Where postwar Britain confronted the loss of empire and France struggled for years to come to terms with Algeria," as Carol Gluck has phrased it, "Japan turned away from its imperial past in Asia into the waiting embrace of the future and of the United States." 28

This embrace, it is important to recognize, was part and parcel of the global Cold War regime. This larger geopolitical framework was a major factor that colluded with, and made possible the postwar marginalization of empire. The imperial retreat in public memory was thus not simply or entirely the product of conscious decisions and vested interests, but was also in some ways the effect of the larger international context. The silencing of Asia corresponded with the great divide of the Cold War, the incorporation of Japan into a Western/capitalist world order dominated by the United States, and the insertion of neighboring countries into Cold War geopolitics less as Asian than as communist. Under the umbrella of the security treaty with the United States, official Japan aligned itself firmly with "the West." In Europe and the United States, as well, the Japan of the economic miracle came to be regarded, in Noam Chomsky's words, "as honorary European." 29

\section{THE EARLY IMPACT OF THE DISSOLUTION OF EMPIRE}

But this was not the entire story. In Japan, as elsewhere, various groups and individuals competed over different versions of the past and its broader significance - accounts of the empire and claims about its continued relevance to society were conflictual and contested. Particularly in the early postwar

27 B.V.A. Röling and C. F. Rüter, The International Military Tribunal for the Far East (IMTFE): The Tokyo Judgment, 29 April 1946-12 November 1948, vol. 1. (Amsterdam: APA-University Press Amsterdam, 1977), 53. See also Awaya Kentarō, Tōkyō saibanron (Tokyo: Ōtsuki Shoten, 1989); Yuma Totani, The Tokyo War Crimes Trial: The Pursuit of Justice in the Wake of World War II (Cambridge: Harvard University Press, 2008).

28 Carol Gluck, “Operations of Memory: 'Comfort Women' and the World,” in Sheila Miyoshi Jager and Rana Mitter, eds., Ruptured Histories: War, Memory, and the Post-Cold War in Asia (Cambridge: Harvard University Press, 2007), 47-77, here 51.

29 Noam Chomsky, "The New World Order," Agenda 62 (1991): 13-15, here 13. 
years, the impact of former imperial links and the effects of the forced severing of them could still be felt in Japan, and traces of the vanished empire lingered on as a sometimes awkward presence. Immediate forgetting does not exhaust the reactions of individuals and interest groups, and through the late 1940s and the 1950s Japanese in some social milieus felt the dissolution of the empire much more deeply than official discourse would suggest.

Furthermore, the embrace by the United States was an anathema to many intellectuals on the left, who pursued radically different political and ideological alternatives. Some Marxist thinkers interpreted U.S. hegemony in the region, and the Japanese government's role as a client state in the new world order, as a new form of colonial relationship, particularly during the 1950s. This can be understood, in part, as a reaction to the so-called "reverse course" in occupation policy, when the earlier focus on democratization was replaced with one on economic recovery, political stability, and anti-communism. That effectively ended what had been the Japanese left's early infatuation with the occupation. ${ }^{30}$ While many intellectuals had welcomed the Americans as a liberation force, they now began to portray their presence in terms of colonial rule. Influential historian Inoue Kiyoshi, for example, described Japan's relationship to its American protector as follows: "For six years we have been deprived of our sovereignty, we have been placed under the occupation of foreign armies; our fatherland is being transformed into a colony more and more every year, and all of Japan is becoming a military base of a foreign power." 31 One venue in which such postcolonial sentiments were expressed was the demands for the return to Japan of Okinawa, in many ways Japan's first colony, annexed in 1879, but now held by the United States (until 1972). ${ }^{32}$

This perspective was also projected onto Japan's past. In the 1950s, historians like Inoue began to wrestle their field's interpretation of the Meiji Restoration away from its exclusive focus on internal class struggle, and instead emphasized the imperialist context of the late nineteenth century. In the early 1960s, historians stressed the Meiji Restoration's commonalities with the Great Rebellion in India (the so-called "mutiny") and the Taiping Rebellion in China, thereby reframing it as an instance of resistance against Western imperialism in Asia. ${ }^{33}$ It is difficult to miss a certain irony in the fact that the

\footnotetext{
30 On the "reverse course," see Howard B. Schonberger, Aftermath of War: Americans and the Remaking of Japan 1945-1952 (Kent, Oh.: Kent State University Press, 1989). For intellectual debates in the early postwar years, see J. Victor Koschmann, Revolution and Subjectivity in Postwar Japan (Chicago: University of Chicago Press, 1996).

31 Inoue Kiyoshi, Nihon gendaishi 1: Meiji Ishin (Tokyo: Chūō kōronsha, 1951).

32 See Yamano Kōkichi, Okinawa henkan hitorigoto (Tokyo: Gyōsei, 1982).

33 Inoue Kiyoshi, Nihon gendaishi 1: Meiji Ishin (Tokyo: Tokyo Daigaku Shuppankai, 1951); Ubukata Naokichi, Tōyama Shigeki, and Tanaka Masatoshi, eds., Rekishizō saikōsei no kadai: Rekishigaku no hōhō to Ajia (Tokyo: Ochanomizu Shobō, 1966).
} 
notion of empire was taken up primarily to portray Japan as the colonized, not the colonizer. One can read this example-along with the dominant trope of erasure - as an attempt to avoid the issue of Japanese imperialism altogether, but this is only partially correct. Many Marxist historians perceived Japanese wartime expansion as but one facet of a larger imperialist project, which they understood in terms of global capitalist exploitation; in this light, their protests against U.S. imperialism in postwar Asia were, in essence, a continuation of their earlier critiques of Japan's imperial projects. ${ }^{34}$

The Chinese revolution in 1949 was a prominent catalyst for debates about a new Asian order that would offer political and cultural options beyond allegiance with the West. The sinologist and cultural critic Takeuchi Yoshimi, an early opponent of Japan's wartime politics of the "Greater East Asian Prosperity Sphere," was the most prominent spokesperson and lobbyist for a Japanese postwar Asian turn. Infatuated with the energy and dynamic of China's social transformation, Takeuchi prescribed China's quest for an indigenous modernity as a remedy for what he perceived to be Japan's empty and derivative westernization. ${ }^{35}$

Beyond these intellectual debates, in the early postwar years the aftereffects of imperial demise were palpable on an everyday level. Most affected were those who had taken part in the massive trans-border mobility that empire had unleashed-expansionist policies had sent millions into the colonies and occupied territories. After 1945, a chief concern of Allied politics was to disentangle the population groups that, in a post-imperial age, were to be allocated to different, sometimes new, nation-states. Some seven million Japanese nationals (about 3.7 million soldiers and 3.2 million civilians) were outside of the Japanese islands at war's end, and they were repatriated to Japan after the surrender. These included large numbers of settlers and their families who, with incentives from and backing by the state, had migrated to Manchuria since the 1920s.

Most of the returning civilians and soldiers arrived in Japan in the immediate aftermath of the war. Before entering the country, they were quarantined aboard ships, and then bathed, disinfected, and inoculated against diseases such as cholera, smallpox, tetanus, and typhus - as if the hygienic measures had the power to wash off the imprint of empire. On the whole, Japanese society did not welcome the returnees, since they added to postwar distress and recalled bygone and now obsolete and defunct imperial ambitions. Late

\footnotetext{
34 Yoon Keu-Cha, "Sengo rekishigaku no Ajiakan," in Asao Naohiro et al., eds., Nihon tsūshi, Bekkan 1: Rekishiishiki no Genzai (Tokyo: Iwanami Shoten, 1995), 249-79; Narita Ryūichi, Kingendai Nihonshi to rekishigaku: Kakikaerarete kita kakkō (Tokyo: Chūō kōronsha, 2012).

35 Takeuchi Yoshimi, Kindai no chōkoku (Tokyo: Chikuma Shobō, 1983). On Takeuchi, see Oguma Eiji, "Minshu” to “Aikoku”: Sengo Nihon no nashonarizumu to kōkyōsei (Tokyo: Shinyōsha, 2002), 394-446; Richard Calichman, Takeuchi Yoshimi: Displacing the West (Ithaca: Cornell East Asia Series, 2004).
} 
returnees, especially, were often greeted with suspicion because they were presumed to have been raped (the women returning from Manchuria) or politically indoctrinated (when returning from the Soviet Union). Many returnees took years to come to terms with the traumas of relocation and integration. While many felt like social outcasts in their home country, others tried to refashion themselves as experts on things foreign, as cultural intermediaries with lived experience overseas. Returnees formed associations and self-help groups, and established newsletters and newspapers, to organize and to lobby the government for compensation. ${ }^{36}$

Conversely, at the war's end large numbers of colonial subjects were living in Japan - an estimated two million Koreans, fifty-six thousand Chinese, and thirty-five thousand Taiwanese. Many had been brought there during the war years, often through forced conscription, and many had worked in harsh and unsafe environments such as coalmines. Immediately after the Japanese surrender, the Allies began to "move people in ways that reversed, at high speed, the migrations of the colonial period." 37 Already by November 1945, about a million Koreans had left, on their own and without official support, and the next four years saw another five hundred thousand depart. During that time, return migration was inhibited by strict regulations that stifled illegal back-and-forth mobility between Japan and Korea. Those who chose to remain-including some six hundred thousand Korean speakers - were subjected to a variety of discriminatory measures, epitomized by symbolic fingerprinting during alien registration. Koreans formed a postcolonial presence that served as a reminder of the imperial past, even though in public discourse much of that experience was subdued well into the $1980 \mathrm{~s} .^{38}$

The peace movement supplies a further example of how memory of Japan's imperial past spilled over into postwar Japanese society. A strong pacifist sentiment developed in the early postwar decades, spurred by both the impact of Hiroshima and Nagasaki and a desire to break with Japan's aggressive foreign policy. Frequently, this sentiment was the product of critical selfappraisal by people who had once supported the regime's wartime efforts or been infatuated with its propaganda promises. The peace movement's leaders were not only intellectuals, and it was supported by grassroots movements and organized labor. Indeed, peace was on the agenda of most social

\footnotetext{
36 See Watt, When Empire Comes Home; Narita Ryūichi, "Hikiage' to 'Yokuryū," in Aiko Kurasawa, ed., Iwanami kōza: Ajia Taiheiyō Sensō, Volume 4: Teikoku no sensō keiken (Tokyo: Iwanami Shoten, 2006).

37 Watt, When Empire Comes Home, 2.

38 John Lie, Zainichi (Koreans in Japan): Diasporic Nationalism and Postcolonial Identity (Berkeley: University of California Press, 2008); Hiroshi Komai, Foreign Migrants in Contemporary Japan (Melbourne: Trans Pacific Press, 2001); Yamawaki Keizō, Kindai Nihon to gaikokujin rōdōsha (Tokyo: Akashi shoten, 1994); Pak Chon Myon, ed., Zainichi Chōsenjin: Rekishi, genjō, tenbō (Tokyo: Akashi shoten, 1995).
} 
movements in the early postwar years. The Korean War further convinced many groups of the urgent need for a rigid anti-war stance, and sparked protests. $^{39}$

But some of the peace movement's actions have exemplified the ambiguous place the former empire occupies in Japanese public memory. For example, while activists sympathized with the struggles of other Asian peoples and denounced war in general terms, only rarely did they explicitly recognize Japan's responsibility for imperial rule and wartime atrocities committed in Asia. And gradually the movement shifted its primary point of reference away from a critique of Japan's own war and toward the renewed nuclear threat. The so-called "Lucky Dragon" incident in 1954, when a Japanese tuna fishing boat was exposed to nuclear fallout from U.S. tests on the Bikini Atoll, allowed Yasui Kaoru to turn the demand for antinuclear peace from a cause driven by leftist labor unions into a non-partisan, middle-of-the-road movement that attracted masses of people, among them many women. The separation of the peace agenda from Japan's imperial past and the focus on the atomic experience as a "singular national principle" (yuiitsu nashonaru (kokuminteki) na genri), as political scientist Sakamoto Yoshikazu called it in 1961, helped to garner popular support for the movement. "While it is unavoidable," Sakamoto declared, "that memories of war damage and awareness of war responsibility tend with the passage of time to be seen as past issues, the issue of nuclear bombs forces itself on us, on the young generations especially, as a future problem."

\section{TRACES OF EMPIRE IN HIGH-GROWTH JAPAN}

As these examples show, while repercussions from the imperial past continued to affect postwar society, memories of empire as expressed in public discourse waned over time. I will argue in this section that the sidelining of the imperial past increased after about 1960, that this marginalization was a feature more of state-sponsored memory and the public sphere than of people's everyday perceptions, and that it was exaggerated, retrospectively, by a historiography that constructed sweeping narratives of Japan's postwar imperial "amnesia."

The timing of this marginalization was not due to internal Japanese trajectories alone, but was also influenced by various international economic and political factors and how they interacted with Japanese developments. Two of these are of special relevance here: First, Japan's economic recovery and emergence as a high-growth nation, beginning in the mid-1950s, together with

39 Mari Yamamoto, Grassroots Pacifism in Post-War Japan: The Rebirth of a Nation (London: Routledge, 2004). For the intellectual background, see Oguma, "Minshu” to "aikoku."

40 Sakamoto Yoshikazu, "Kenryoku seiji to heiwa undō," Sekai 191 (Nov. 1961), 11-23, here: 20. See also James Orr, The Victim as Hero: Ideologies of Peace and National Identity in Postwar Japan (Honolulu: University of Hawai`i Press, 2001). 
political consolidation in the so-called "1955 system," which secured a quasimonopoly on political power for the Liberal Democratic Party, created through a merger of two conservative parties, strengthened Japan's alignment with the industrialized countries of the West and further distanced it from Asia. Second, the large civil-society movement that opposed the Japan-U.S. security treaty was defeated in violent struggles in 1960, and this both solidified Japan's position on the Western side of the Cold War divide, and undermined activists and social reformers who had worked to sustain a public, critical perspective on Japan's imperial past. ${ }^{41}$ These larger processes did not automatically lead to an eclipse of empire, but they all helped create structures that facilitated the pursuit of an agenda of imperial ignorance, and made it more difficult and less plausible for social groups to insist on the relevance of such memories.

As a consequence, by the 1960s the imperial past was subsumed under what historians have termed the "victim consciousness" of postwar Japan. As James Orr has argued, the notion of victimhood had emerged as the dominant discourse about the recent past, tapped into by groups across the political spectrum. Within this logic, the Japanese nation was depicted as the object of suppression, power, and circumstance: honorable politicians (and the emperor) were the victims of staunch militarists, the people were victims of their leaders, and Japan was the first and sole victim of the atomic bomb. ${ }^{42}$ Only a small number of oppositional activists picked up the memory of Japanese atrocities, such as the Nanjing massacre and the experiments in biological warfare. These critical voices were largely neglected, and even suppressed, in official and state-sponsored memory, which was influenced by powerful groups of former imperialists disinclined to address their personal wartime roles. ${ }^{43}$

Against this backdrop of widespread victim consciousness, some Japanese nationalists began to denounce their country's dependent position within what they perceived to be an informal U.S. empire. The most prominent example was Hayashi Fusao's book Approving of the Greater East Asian War, which provoked a public stir when it was published in 1964. Hayashi interpreted all of modern Japanese history, from 1853 when American ships landed in the bay of Uraga to 1952 when American occupation forces left the country, as a

41 George R. Packard, Protest in Tokyo: The Security Treaty Crisis of 1960 (Princeton: Princeton University Press, 1966); Wesley Sasaki-Uemura, Organizing the Spontaneous: Citizen Protest in Postwar Japan (Honolulu: University of Hawai`i Press, 2001).

42 For the occupation period, see John Dower, Embracing Defeat: Japan in the Wake of World War II (New York: Norton, 1999); Monica Braw, The Atomic Bomb Suppressed: American Censorship in Occupied Japan (New York: M. E. Sharpe, 1991).

43 See Orr, Victim as Hero; Franziska Seraphim, War Memory and Social Politics in Japan, 1945-2006 (Cambridge: Harvard University Press, 2006). For the concept of "victimhood nationalism," see also Jie-Hyun Lim, "Victimhood Nationalism in Contested Memories: National Mourning and Global Accountability," in Aleida Assmann and Sebastian Conrad, eds., Memory in a Global Age: Discourses, Practices and Trajectories (New York: Palgrave Macmillan) 2010, $138-62$. 
"Hundred Years War" against the West. From this view, the Second World War appeared as a mere episode in an epic struggle between Asia and the "West." According to Hayashi, Japan during this period had taken on the task of freeing Asia from Western influence. "The Great Asian War ... was the fate which had been placed on Japan's shoulders over these hundred years."44

Even if such extreme views remained, on the whole, a minority position, they demonstrate the extent to which it was again possible to employ an openly imperialist rhetoric. Hayashi's polemic is representative of the tendency to slight Japan's aggressive and expansionist politics in Asia. The book mapped Japan decidedly as an Asian nation, and through its explicit discussion of the Japanese Empire it drew on strands of memory that in the public sphere were frequently disavowed. This dialectic of marginalization and remembering characterized much of the period between the mid-1950s and the 1980s.

On one hand, the public relevance of the imperial past did decrease, and Japan's incorporation into the Cold War regime helped delete, to some extent, the former empire from public consciousness. The seismic shift in Japan's postwar geopolitical orientation led large parts of the population, among them critical intellectuals and social reformers, to frame their visions of Japan's past and future squarely within the borders of the nation-state. On the other hand, the social experience of empire never entirely disappeared. But the remaining traces of imperial connections were frequently rendered invisible by a discourse that celebrated Japan as Western, democratic, and fundamentally newborn.

A telling example of this dialectic is found in narratives of the recent war. Up until surrender in 1945, the wartime regime had glorified the conflict as the "Greater East Asian War" (daitōa sensō), a propaganda term coined just a few days after the attack on Pearl Harbor. One of the first interventions by the American occupation authorities was to prohibit further use of this label. Instead, 'Pacific War' (taiheiyō sensō) was introduced as the official name in Japan of the Second World War. The change in vocabulary had a double effect. Ostensibly it was directed against revisionist historiography, which sought to justify the war as a gift by the Japanese to the suppressed peoples of Asia. More importantly, it implied a fundamental shift in the spatial imaginary of the conflict: the geographical center of the war was no longer China, where Japanese armies had fought for nearly fourteen years, exacting an estimated toll of over twenty million Chinese lives. Instead, the conflict with the United States took center stage, with the attack on Pearl Harbor as the historical watershed that gave the war its meaning and its name. ${ }^{45}$

${ }^{44}$ Hayashi Fusao, Daitōa sensō kōteiron (Tokyo: Banchō Shobō, 1964).

45 Richard Minear, "Nihon no rekishika to sensō, 1945-1965nen," in Nakamura Masanori et al., eds., Sengo Nihon. Senryō to sengo kaikaku, Volume 5: Kako no seisan (Tokyo: Iwanami Shoten, 1995), 133-56. 
Despite this interpretative imbalance, the imposition of the new label was highly effective and endured long after the occupation had ended. Indeed, it rendered it difficult to address the war's Asian dimensions. When historian Ienaga Saburō presented his now classic study of the war in 1968, against the background of the student movement and the widespread concern with the "Third World," he chose to focus primarily on the war on the Asian mainland, particularly in China. He nevertheless opted to call his book "The Pacific War," because otherwise - as he admitted in the preface - he feared that readers would not know what the book was actually about. ${ }^{46}$

In this discursive landscape, political claims made with respect to the country's colonial past could prove difficult to register. Many of the concerns of and demands made by former colonized nations reverberated only weakly in Japan. An example is the negotiations over normalization of relations with South Korea, conducted in 1964-1965 between Prime Ministers Ikeda and Satō, as well as Korean President Park Chung Hee. Under massive U.S. pressure, Japan was willing to settle accounts with the past and assist an economically ailing Korea, but only under the condition that South Korea would renounce its right to demand reparations and not press for an official apology. In return, Japan agreed to pay large sums that the treaty's official wording portrayed, not as compensation for wartime crimes and colonial rule, but rather as "economic cooperation."

Victim consciousness, and a concomitant negligence of imperial traces, was the hegemonic discourse of the long postwar decades, and this has led many commentators to conclude that a critical consciousness of decolonization failed to emerge in high-growth Japan. ${ }^{48}$ As apposite as this observation is, it should not lead us to ignore counterexamples altogether. There was never an absolute lack of critical reflection on Japan's wartime empire. ${ }^{49}$ Recent scholarship has begun to unearth the largely forgotten history of Japanese engagements with Asia. Individuals and pressure groups occasionally did campaign for anti-imperialist views of the colonial legacy. The range of interest groups and memory activists was heterogeneous and diverse. On the political left, organizations such as the Teacher's Union and the General Council of Trade Unions were sympathetic to critical readings of Japan's Asian past, and specific interests groups such as the Japan-China Friendship Association denounced

${ }^{46}$ Ienaga Saburō, Taiheiyō sensō (Tokyo: Iwanami Shoten, 1968), 4.

47 See Seraphim, War Memory, 202-6; Asano Toyomi, "The Collapse of the Japanese Empire and the Normalization of Its Relations with South Korea (1945-1965): Repatriation, Reparations, and External Assets Reconsidered," in Matsusato Kimitaka, ed., Comparative Imperiology (Sapporo: Slavic Research Center, 2010), 109-29.

${ }_{48}$ Kang Sang-Jung, Ajia kara Nihon o tou (Tokyo: Iwanami Shoten, 1994); Kuan-Hsing Chen, Asia as Method: Toward Deimperialization (Durham: Duke University Press, 2010).

49 For an early example, see Ubukata Naokichi, Tōyama Shigeki, and Tanaka Masatoshi, eds., Rekishizō saikōsei no kadai: Rekishigaku no hōhō to Ajia (Tokyo: Ochanomizu Shobō, 1966). 
"American imperialism" and a resurging "Japanese militarism" in the late 1960 s. $^{50}$ In some cases, such as that of the Philippines, reconciliatory practices emerged out of instances of mutual remembrance that would eventually lead to official Japanese apologies, which did not find an equivalent in most other countries. $^{51}$

One early witness of this process was the journalist Honda Katsuichi. His experience in Southeast Asia helped motivate him to embark on a study tour through China in the early 1970s. His travel reports (serialized as Chûgoku no tabi in 1971) and his interviews with victims of Japanese atrocities were intended to undermine the prevalent notion of Japan as a victim nation. His unearthing of the gruesome facts about the Nanjing massacre in 1937 triggered a heated public debate. The conservative mainstream denied any such allegations, but beginning in the mid-1970s, the first careful accounts of the massacre began to make their way into high school textbooks. ${ }^{52}$ The debate about Nanjing also worked to support the case of historian Ienaga Saburō, who sued the Japanese state in a trial over textbook censorship that, together with its various ancillary procedures, lasted until the 1990s. Ienaga, whose struggle was supported by a number of civic grassroots organizations, campaigned for a critical perspective on the war, and on Japan's actions in its Asian empire. ${ }^{53}$

The Vietnam War did much to mobilize thinkers and activists on the left. Many of them assailed the political establishment, which they saw to be responsible for Japan's alignment with the Western countries against their brothers and sisters in Asia. The public outcry over U.S. atrocities in Southeast Asia led some, like Honda Katsuichi, to probe Japan's own violent past in Asia, and novels like Ibuse Masuji's Black Rain (Kuroi ame) testify to the Vietnam War's role as a catalyst for critical reappraisals of Japan's imperialist history. ${ }^{54}$

At the same time, the fervent and at times violent movement against the Vietnam War was ambiguous in how it drew upon Japan's own imperial past. For one prominent spokesperson of the movement, Oda Makoto (1932-

50 Seraphim, War Memory.

51 Nakano Satoshi, Tōnan Ajia senryō to Nihonjin: Teikoku/Nihon no kaitai (Tokyo: Iwanami shoten, 2012).

52 Katsuichi Honda, The Nanjing Massacre: A Japanese Journalist Confronts Japan's National Shame (Armonk: East Gate Book 1999). On the debate, see Takashi Yoshida, The Making of the "Rape of Nanking": History and Memory in Japan, China, and the United States (Oxford: Oxford University Press, 2006).

53 On the Ienaga trials, see B. C. Duke, Japan's Militant Teachers: A History of the Left-Wing Teachers' Movement (Honolulu: University of Hawai i Press, 1973); Laura Hein and Mark Selden, eds., Censoring History: Citizenship and Memory in Japan, Germany, and the United States (Armonk: M. E. Sharpe, 2000).

54 Oguma Eiji, "Minshu” to "aikoku”; Oguma Eiji, "The Postwar Intellectuals' View of “Asia,"” in Sven Saaler and J. Victor Koschmann, eds., Pan-Asianism in Modern Japanese History: Colonialism, Regionalism and Borders (London: Routledge, 2007), 200-12; Thomas R. H. Havens, Fire across the Sea: The Vietnam War and Japan, 1965-1975 (Princeton: Princeton University Press, 1987). 
2007), the "most important factor" of his commitment to the protests against U.S. imperialism in East Asia was his "war experience of twenty-one years ago," and thus the "experience of a victim." Oda mentioned Japan's imperial role in Southeast Asia only in passing; and when he did, he referred to a war that "in effect ... resulted in the liberation and independence of Asia and Africa." Privileged as a parallel to the American bombing of Vietnam were the American air raids on Osaka in 1945, not the Japanese attacks on Southeast Asia. This characteristic superimposition of the Second World War on the Vietnam War allowed some Japanese activists to read their protest against U.S. imperialism as part of a shared Asian struggle. ${ }^{55}$

In many cases, then, the former colonial links fell into oblivion. Even where traces of empire persisted, they could be discursively erased by stripping them of their imperial connotations. Examples are manifold, and include the ongoing territorial dispute over the Linancourt Rocks-known as Dokdo in Korean and Takeshima in Japanese - annexed in 1905 when Japan established a protectorate over Korea. ${ }^{56}$ Another case in point is the role of Korean and Okinawan workers whose low-paid labor was integrated into the Japanese economy in the 1960s. In general, labor immigration had a modest impact on Japanese economic growth, but in specific industries, especially in the Kansai region, the contribution of their work was felt, if hardly recognized. Less acknowledged still were the imperial structures that had propelled these workers into Japan's mining and construction sectors in the first place. ${ }^{57}$

Similarly, Japan's foreign aid through the mid-1980s went primarily to territories formerly subjected to Japanese rule. In the wake of the 1951 peace treaty with the United States, Japan agreed to pay reparations for damages caused by the war. Though these expenditures were relatively small, they worked to the long-term advantage of Japanese exports. Because aid was mostly tied to procurements from Japan, the donations helped Japanese financial institutions make inroads and established markets for Japanese goods. Yet the structural links to the former empire were hardly discussed. ${ }^{58}$

Finally, the debates about Japan as a developmental state, and about the way in which the high growth of the 1960s was predicated on a corporate

\footnotetext{
55 Quotes from Simon Andrew Avenell, Making Japanese Citizens: Civil Society and the Mythology of the Shimin in Postwar Japan (Berkeley: University of California Press, 2010).

${ }_{56}$ See Paul Midford, "Challenging the Democratic Peace? Historical Memory and the Security Relationship between Japan and South Korea," Pacific Focus 23, 2 (2008): 189-211.

57 See Hiromi Mori, Immigration Policy and Foreign Workers in Japan (New York: St. Martin's Press, 1997); Lie, Zainichi; Tessa Morris-Suzuki, Borderline Japan: Foreigners and Frontier Controls in the Postwar Era (Cambridge: Cambridge University Press, 2010); Komai, Foreign Migrants. For a longer historical perspective, see Ken C. Kawashima, The Proletarian Gamble: Korean Workers in Interwar Japan (Durham: Duke University Press, 2009).

58 On Japanese foreign aid in the 1960s and 1970s, see E. C. Harrell, Japan's Postwar Aid Policies (New York: Columbia University Press, 1973); Kunio Yoshihara, Japanese Investment in Southeast Asia (Honolulu: University of Hawai`i Press, 1978).
} 
"system" established in the 1930s and 1940s, have largely followed a similar pattern. Rarely explored is the extent to which this restructuring, and possibly also postwar growth, was linked to economic integration in East Asia, particularly the incorporation of Manchuria, that was made possible by imperial structures. ${ }^{59}$ In sum, postwar Japan was built, in complex ways, on colonial legacies that were to a large extent obscured. ${ }^{60}$

One place where this is apparent is in the many retrospective narratives produced by soldiers and settlers who returned from the empire. As already noted, close to seven million Japanese were moved back to the archipelago in the wake of defeat and surrender in 1945. Starting in the 1950s, official histories of repatriation were published by the Health Ministry, as the institution responsible for the return. In addition, individual returnees published their memories, mostly between 1960 and 1990. Most of these texts evoked the notion of a clinical separation of Japan from its empire, and most begin their account on 15 August 1945, the day of the surrender. In this way, the imperial past disappeared from the biographies of the very Japanese that had made the empire. $^{61}$

A similar pattern can be observed in the very different and in many ways exceptional cases of the stragglers - the late-returning soldiers. Throughout the 1950s, Japanese soldiers occasionally returned to Japan from battlefields in Southeast Asia where they had endured, hidden, and sometimes fought imagined enemies long after the war's end. Those who came back in the early postwar period were either ignored or treated as aberrations, as wild jungle men. Their reception changed considerably in later years, when the individuality of the returning soldiers was increasingly recognized, and their attitude was praised as exemplary patriotism. The most celebrated case was Onoda Hirō, who surrendered in 1974 after having held out for almost thirty years in Philippine's jungle. Onoda apparently did not know that the war had ended; over the years he had killed about thirty Filipinos and was willing to surrender only to his former wartime commanding officer. He was immediately popular in Japan, and published a best-selling autobiography. Strikingly, however, in public discourse even Onoda was not primarily associated with empire, but was hailed as

59 See Chalmers Johnson, MITI and the Japanese Miracle: The Growth of Industrial Policy, 1925-1975 (Stanford: Stanford University Press, 1982); John Dower, "The Useful War," in J. Dower, ed., Japan in War and Peace (New York: New Press, 1993), 9-32; Noguchi Yukio, 1940 nen taisei (Tokyo: Tokyo Keizai Shimpōsha, 1995).

60 On the level of popular culture, see Yoshikuni Igarashi, Bodies of Memory: Narratives of War in Postwar Japanese Culture, 1945-1970 (Princeton: Princeton University Press, 2000).

61 See Mariko Asano Tamanoi, Memory Maps: The State and Manchuria in Postwar Japan (Honolulu: University of Hawai i Press, 2009); Watt, When Empire Comes Home; Narita Ryūichi, "Hikiage' to "yokuryū"”; Nicole Leah Cohen, "Return of the Natives? Children of Empire in Post-Imperial Japan," in Ulbe Bosma, Jan Lucassen, and Geert Oostindie, eds., Postcolonial Migrants and Identity Politics: Europe, Russia, Japan and the United States in Comparison (New York: Berghahn Books, 2012), 155-79. 
representing spiritual and social values that seemed to have vanished in materialist and consumerist Japan. ${ }^{62}$

\section{MODERNIZATION THEORY AND THE MARGINALIZATION OF EMPIRE}

The public marginalization of the imperial past was part and parcel of a foundational narrative of internal and self-induced development that became hegemonic in the 1950s and 1960s. Within this narrative structure, Japan was severed from its regional contexts and portrayed as a society that had transformed entirely from within. This overarching paradigm was corroborated by both the dichotomies of the Cold War regime and the seemingly self-generated take-off of Japan's high-growth economy. On a discursive level, it was supported, and naturalized, by the rise of modernization theory.

Much has been written about the global diffusion of modernization theory in the 1950s and 1960s as a new and decidedly anti-Communist ideology of development. ${ }^{63}$ Conventionally, the arrival of modernization theory in Japan has been interpreted as an import, linked to the "Conference on Modern Japan" held in the summer of 1960 in Hakone, a small hot-springs resort town just outside of Tokyo. The Ford Foundation sponsored the event, which was prominently attended by American Ambassador Edwin O. Reischauer, who saw exportation of modernization theory to be part of a larger U.S. strategy in the global Cold War. ${ }^{64}$ As a result, many Japanese commentators saw the project of rewriting the Japanese past, and of using an abstract notion of "modernization" as the measure of social development, as thinly veiled forms of cultural imperialism under the geopolitical conditions of the Cold War. ${ }^{65}$

But this diffusionist account obscures the complex processes of knowledge production and transnational exchange through which the notion of modernization took hold in postwar Japan. Modernization theory was in many ways

\footnotetext{
62 See Beatrice Trefalt, Japanese Army Stragglers and Memories of the War in Japan, 19501975 (London: Routledge, 2003); Wakaichi Kōji, Saigo no senshisha (Tokyo: Kawade Shobō, 1986).

63 See Michael H. Hunt, The American Ascendancy: How the United States Gained and Wielded Global Dominance (Chapel Hill: University of North Carolina Press, 2007); David Ekbladh, The Great American Mission: Modernization and the Construction of an American World Order (Princeton: Princeton University Press, 2010).

64 For accounts of the Hakone Conference, see Victor Koschmann, "Modernization and Democratic Values: The 'Japanese Model' in the 1960s," in David C. Engerman et al., eds., Staging Growth: Modernization, Development, and the Global Cold War (Amherst: University of Massachusetts Press, 2003), 225-50; Stefan Tanaka, "Objectivism and the Eradication of Critique in Japanese History," in Masao Miyoshi and Harry D. Harootunian, eds., Learning Places: The Afterlives of Area Studies (Durham: Duke University Press, 2002), 80-102; Sebastian Conrad, "The Colonial Ties Are Liquidated: Modernization Theory, Postwar Japan and the Global Cold War," Past \& Present 216 (2012): 181-214.

65 See, for example, Wada Haruki, "Gendaiteki 'Kindaika'ron no shisō to ronri," Rekishigaku kenkyû 318 (1966): 2-12.
} 
compatible with, and indeed was grafted onto, earlier Japanese theories of modernization. Beginning in the mid-1950s, a Japanese version of the modernization concept had emerged that purported to explain the sudden economic recovery and take-off. Even earlier, during the war years, historians like Ötsuka Hisao (1907-1996) had mined the work of Max Weber to develop a theory of modernization that in many respects prefigured Parsonian modernization theory of the 1960s. Thus American influences alone cannot explain the hegemony of the "modernization" concept in Japan, and it must be understood as a specific response to Japan's postwar situation. ${ }^{66}$

For our purposes here, the various genealogies of modernization in Japan are less important than the fact that all available versions of modernization theory, whether "indigenous" or imported, operated within an internalist framework. They gave only marginal attention to foreign influences, trans-border contacts, transfers from abroad, or exchange and migration-the focus was entirely on internal dispositions and mechanisms of internalization. This celebration of endogenous development culminated in the apotheosis of Robinson Crusoe, Max Weber's "isolated economic man."67 "What impressed us," admitted Ōtsuka in 1947, "was that he was organizing the reality he was facing by creating a rational system of production ... on such an isolated island." 68

Ōtsuka translated Crusoe-the quintessential modernizer sui generis, autonomous and relying on his own capacities - to the situation of postwar Japan. In this reading, Japan likewise was expected to develop from within, to rise like a phoenix from the ashes, and to modernize entirely on its own. This was a view of the past that wrote Japan out of the world-just as the logic of the Cold War seemed to have extricated Japan from its East Asian contexts.

In many ways, this paradigm corresponded with a fundamental transformation of the ideological make-up of postwar Japan, and of what it meant to be "Japanese." Oguma Eiji revealed one striking characteristic of this when he demonstrated how, after 1945, the discourse on the ethnic foundations of the nation underwent significant changes. The dominant discourse during the war had represented the Japanese people as ethnically diverse (kongo minzoku ron). In its essence, this ideology was distinctive to the Japanese Empire, and displayed characteristic differences from the ideologies of

\footnotetext{
${ }^{66}$ To be sure, Ōtsuka's was a negative view of Japanese modernization, which he saw to be characterized by structural deficits and an incomplete transition to modernity. See Sebastian Conrad, The Quest for the Lost Nation: Writing History in Germany and Japan in the American Century (Berkeley: University of California Press, 2010), 178-84.

${ }^{67}$ Max Weber, Die Protestantische Ethik und der Geist des Kapitalismus (Munich: C. H. Beck, 2004), 197.

${ }^{68}$ Ōtsuka Hisao, "Robinson Kurūsō no ningen ruikei," in Ōtsuka Hisao chōsakushû, vol. 8 (Tokyo: Iwanami Shoten, 1969), 215.
} 
European empires. The Japanese, in this model, were an amalgamation of southern and northern Asian peoples, including the native populations of Taiwan and Korea. The union of these peoples within the Japanese Empire could thus be interpreted not as an annexation but as a form of homecoming.

This perspective disappeared along with the empire, and in 1945 lost all plausibility. The dominant discourse from then on rested on the construction of a homogeneous Japanese people (tan'itsu minzoku ron), who dwelled on their peaceful archipelago in ethnic isolation and purity. ${ }^{69}$ This view continues to hold sway over the academic and popular self-assurance of the Japanese nation today, with important social and juridical consequences. In 1951, this new conception of the nation was legally confirmed when, in the Peace Treaty of San Francisco, Japan renounced all territorial claims in Korea, Taiwan, and Southeast Asia. From 1952 onward, the Japanese government treated as foreigners all Koreans and Taiwanese who until then had been Japanese citizens, with major implications for their freedom of movement, their access to the labor market, and their claims to the benefits of the health and social security systems. ${ }^{70}$ This transformation of the Japanese imagination, and of the legal definition of who counted as "Japanese," corresponded to both the exigencies of the global Cold War and the vanishing of empire. ${ }^{71}$

\section{JAPAN IN ASIA IN THE $1990 \mathrm{~S}$}

Japan's empire did not fully return to the stage of public debate until the 1990s, when it did so with a vengeance. Many perceived the January 1989 death of Emperor Hirohito - the head of state since 1926 and a symbolic figure of Japan's wartime experience-as lifting a taboo on speaking about the empire. ${ }^{72}$ More generally, the Cold War's end helped to open up a new space for debate, for new social actors and dissenting voices, and it produced dramatic changes in the landscape of Japanese memory. The fall of the Berlin Wall and the breakdown of the Soviet Union were indicative of the end of the postwar world order in the broadest sense. As the East-West dichotomy faded, so too did its clear-cut framework, which had hitherto seemed to endow all events with political meaning. In many respects, symbolic conflicts over the meanings of the past

69 The prewar discourse of the composite nation was not uncontested, and some authors emphasized absolute racial differences in East Asia. For an assessment of these different positions, see Oguma Eiji, Tan'itsu minzoku shinwa no kigen: Nihonjin no jigazō no keifu (Tokyo: Shinyōsha, 1995).

70 See Won Soon Park, "Japanese Reparations Policies and the 'Comfort Women' Question," Positions: East Asia Cultures Critique 5 (1997): 107-34. See also Sonia Ryang and John Lie, eds., Diaspora without Homeland: Being Korean in Japan (Berkeley: University of California Press, 2009).

71 See also Ching, "Give Me Japan."

72 Norma Field, In the Realm of a Dying Emperor: A Portrait of Japan at Century's End (New York: Vintage, 1993); Ian Buruma, Wages of Guilt: Memories of War in Germany and Japan (London: Phoenix, 1994). 
took the place of earlier ideological antagonisms. ${ }^{73}$ As a result, the 1990 s brought what we might call an explosion of memory talk in Japan.

The most notable effect of the Cold War's end was the change it spawned in Japan's relationship to her Asian neighbors. After a long period of relative ignorance about the region among Japanese, the most important development in the 1990s was what many perceived to be a return of "Asia." There were extended debates about Japan's role in Asia, fledgling forms of regional political cooperation emerged, trade within Asia soared, and not least, vociferous discussions took place about the legacy of Japan's imperial past. In contrast to the public debates during the long postwar decades, these responded to interventions from memory activists in other Asian countries. Most notably, in 1995, on the fiftieth anniversary of the war's end, many Asian governments and civil society groups demanded that the Japanese government make an official apology for encroachments and atrocities during the time of empire. ${ }^{74}$ Debates about empire in Japan from that point onward can only be understood within this broader context - those addressing issues of how to deal with the past have had to constantly negotiate this highly disputed terrain. ${ }^{75}$

This context generated a number of heated debates that have reinstituted the problem of empire as a central concern of public memory. The imperial dimension of memory politics began to be played out in different arenas, all of them highly contested and conflictual, to an extent that sociologist Kang Sang-Jung wrote of a "civil war over memory." While many of the issues had previously been fought over by smaller expert communities and interest groups and their constituencies, the debates now reached a mass audience and polarized public opinion. For one example, discussions of the Nanjing massacre resurfaced. These already had a long history, but the issue was now used to stake out diametrically opposed claims. Within nationalist discourse, the atrocities were frequently denied, most prominently by Tokyo Mayor Ishihara Shintarō, who denounced the term "massacre" as an invention of the Chinese for propaganda purposes. Authors at the other end of the political spectrum, too, did their best to popularize the issue, for example in the pamphlet Thirteen Lies by the Deniers of the Nanjing Massacre, written in everyday language and intended to appeal to a large, general public. ${ }^{76}$

\footnotetext{
73 See Carol Gluck, "The 'End' of the Postwar: Japan at the Turn of the Millennium," Public Culture 10 (1997): 1-23.

74 Seraphim, War Memory. See also Julia Adeney Thomas, "Landscape's Mediation between History and Memory: A Visual Approach to Japan's Past, 1870-1945," East Asian History 36 (2008): 55-72.

75 On the conflictual terrains of memory production between Japan and Korea in particular, see Alexis Dudden, Troubled Apologies among Japan, Korea, and the United States (New York: Columbia University Press, 2008).

${ }^{76}$ Nankin jiken chōsa kenkyûkai, Nankin daigyakusatsu hiteiron 13 no uso (Tokyo: Kashiwa Shobō, 1999). For an analysis of this debate, see Joshua A. Fogel, The Nanjing Massacre in History and Historiography (Berkeley: University of California Press, 2000).
} 
Another issue that came to the fore was the treatment of laborers who had been coerced into serving private Japanese companies between 1939 and 1945. The system had involved millions of people, most notably from Korea but also from many other East and Southeast Asian countries. Through different types of mobilization, ranging from deceptive recruitment to forms of enslavement, workers were forced into a production process that was frequently brutal and led to high mortality rates. Since most victims were illiterate, and the Japanese later destroyed much of the relevant documentation, public consciousness of the issue in Japan emerged relatively late compared with the awareness of forced wartime labor in Europe. Beginning in the 1990s, former forced workers gradually came to be recognized as war victims, and the first schemes of compensation were developed. ${ }^{77}$

But the most conspicuous site for the reemergence of memories of empire has been the issue of compensation for former so-called "comfort women" (jûgun ianfu), a euphemistic term for women forced to be prostitutes in the service of the Japanese army. During the war years, this system of sexual slavery victimized an estimated eighty to two hundred thousand women and girls from throughout Asia, particularly Korea and China. That there had been such a system of forced prostitution was by no means unknown, but it had not been a part of the public memory of the war. The matter entered public consciousness only after the mid-1990s, as a result of a complex interplay of individual agency and institutional lobbying. Women's groups in Korea and in Japan took up the issue and, although governments continued to ignore it, created a public space for its discussion that eventually made it possible for former forced prostitutes to come forward and speak of their personal experiences. The media then picked up the topic, and as pressure on the Japanese government grew, the so-called "Asian Women's Fund" was established in 1995 with the avowed aim of compensating former "comfort women." In Japan and in neighboring countries alike the fund met a wave of criticism for deflecting state responsibility by making the compensation a private rather than a governmental task. Many former victims of the sex-slave system consequently refused compensation because it allowed the state to avoid acknowledging responsibility. ${ }^{78}$

77 Yamada Shōji, Koshō Tadashi, and Higuchi Yūichi, Chōsenjin senji rōdō dōin (Tokyo: Iwanami Shoten, 2005); Paul A. Kratoska, Asian Labor in the Wartime Japanese Empire: Unknown Histories (Armonk: M. E. Sharpe, 2005).

78 On the issue of forced prostitution, see Yoshimi Yoshiaki, Comfort Women: Sexual Slavery in the Japanese Military during World War II (New York: Columbia University Press, 2000); Yuki Tanaka, Japan's Comfort Women: Sexual Slavery and Prostitution during World War II and the US Occupation (London: Routledge, 2002); Chunghee Sarah Soh, The Comfort Women: Sexual Violence and Postcolonial Memory in Korea and Japan (Chicago: University of Chicago Press, 2009). 
The return of empire to public debate in Japan has been remarkable in many respects, but two aspects require special attention here. One is that the phenomenon is not limited to any one part of the political spectrum; the issue is pervasive, and questions of the implications of the former empire and its relevance to the present and future are almost ubiquitous. ${ }^{79}$ On one side, critical and oppositional voices have made convincing claims that coming to terms with the Japanese past must be based on a thorough engagement with the history of empire. A case in point was the International Women's War Crimes Tribunal conducted in Tokyo in the year 2000 with the explicit aim of revisiting, and thereby improving upon, the War Crimes Trial of 1946. The latter was increasingly seen as having eschewed the issue of empire and, much noted in this context, having ignored the crimes committed against women. ${ }^{80}$

Within the academy, the rise of postcolonial scholarship created a space for the recognition of empire as one of the enabling structures of Japanese modernity, and for the re-imagining of Japanese history in Asia. The colonies had long been treated mostly as an appendix to narratives that focused on the internal dynamics of Japanese modernization. To the extent that Japanese colonialism was mentioned, it was interpreted as but an extension and copy of prior developments in the metropole. ${ }^{81}$ Under the influence of postcolonial studies, the framework has fundamentally changed, and recent scholarship has explored the extent to which the social transformations of modern Japan need to be situated within a broader, colonial setting. Landmark studies have included Kan Sang Jung's notion of the Orientalizing gaze as precondition for Japanese modernity, Komagome Takeshi's work on the role of the colonial "Other" in constructing Japanese cultural identity, and research into the standardization of the Japanese language (kokugo) under conditions of coloniality. ${ }^{82}$ More recently, scholars have moved beyond the realms of discourse and representation to look at the ways in which the colonies were treated by bureaucrats, the military, and reformist intellectuals as privileged sites where social interventions could be tested. In these studies, the formation of modernity in Japan and in her colonies is increasingly analyzed within a single analytical field.

The intention to link the critical perspectives on empire to a broader historical consciousness has led to initiatives to write a textbook that captures perspectives from the different countries involved. Throughout Japan's postwar

79 See Iwasaki Minoru et al., eds., Keizoku suru shokuminchishugi: Jendā, minzoku, jinshu, kaikyû (Tokyo: Seikyûsha, 2005).

80 See VAWW-NET Japan, Nihon gunsei doreisei o sabaku: 2000nen josei kokusai senpan hōteino kiroku, 5 vols. (Tokyo: Ryokufu Shuppan, 2000-2002).

81 See Schmid, "Colonialism and the "Korea Problem.",

82 Kang Sang-jung, Orientarizumu no kanata e; Komagome Takeshi, Shokuminchi teikoku Nihon no bunka tōgō; Yi Yŏn-suk, 'Kokugo' to iu shisō (Tokyo: Iwanami Shoten, 1996); Yasuda Toshiaki, Shokuminchi no naka no 'kokugogaku' (Tokyo: Sangensha, 1997). See also Motoyama Tetsuya, Posuto koroniarizumu (Tokyo: Iwanami Shoten, 2005). 
history, school textbooks have been one of the crucial sites where divergent claims to the past were negotiated across the deep chasms between oppositional academics, the state establishment, and nationalist groups. The 2005 publication of a joint textbook co-authored by historians from China, South Korea, and Japan was therefore a highly symbolic event. Its aim was to articulate the modern history of East Asia from three different, albeit intertwined perspectives, with a specific focus on empire. ${ }^{83}$ The book sold over seventy thousand copies in Japan, thirty thousand in South Korea, and one hundred and twenty thousand in China, even though it was not officially approved and so was not used in schools. This tripartite text was the most spectacular among a number of multilateral initiatives between Japan, South Korea, and China. Though it remained firmly wedded to narratives of national history, juxtaposing three "national" interpretations of selected events, it nevertheless benefited from recent attempts by historians to interpret the past in a framework that transcended national borders. ${ }^{84}$ The book is part of a larger move toward reinscribing Japanese history within an Asian context, ${ }^{85}$ and recognizing the importance of East Asian "sites of memory" for locating Japan within the current global conjuncture. ${ }^{86}$ One of the most conspicuous historical moments in this "Asianization" of the Japanese past - one that marked a clear break from the erasure of empire during the "long postwar" periodwas when an influential 2005 publication designated the wartime period as the "Asia-Pacific War" (Ajia Taiheiyo Sensō). ${ }^{87}$

The return of the empire was not only of concern to the self-styled progressive left. On the political right, the memory of Japan's colonial project now experienced renewed popularity. A recent example is a scandal surrounding General Tamogami Toshio, who in October 2008 demonstratively defended Japan's colonialism and war actions. ${ }^{88}$ The case for a more positive evaluation of the country's imperial past-in some ways comparable to French

\footnotetext{
83 Nitchūkan Sangoku Kyōtsū Rekishi Kyōzai Iinkai, Mirai o hiraku rekishi: Ajia sankoku no kingendaishi (Tokyo: Kōbunken, 2005).

84 Sakai Naoki, Brett de Bary, and Iyotani Toshio, eds., Nashonariti no datsukōchiku (Tokyo: Kashiwa Shobō, 1996); Komori Yōichi and Takahashi Tetsuya, eds., Nashonaru hisutorī $\bar{O}$ koete (Tokyo: Tokyo Daigaku Shuppankai, 1998); Jie Liu, Hiroshi Mitani, and Daqing Yang, Kokkyō o koeru rekishi ninshiki: Nitchū taiwa no kokoromi (Tokyo: Tokyo Daigaku Shuppankai, 2006); Hiroshi Mitani and Tae-Chang Kim, eds., Higashi Ajia rekishi taiwa-Kokkyō to sedai o koete (Tokyo: Tokyo Daigaku Shuppankai, 2007).

85 Okamoto Takashi, Sekai no naka no Nisshin-Kan kankeishi: kōrin to zokkoku, jishu to dokuritsu (Tokyo: Kōdansha, 2008).

86 See Itagaku Ryûta, Chon Jiyon, and Iwasaki Minoru, eds., Tōajia no kioku no ba (Tokyo: Kawade Shobō, 2011).

87 Kurasawa Aiko et al., eds., Kōza-Ajia Taiheiyō Sensō, vols. 1-8 (Tokyo: Iwanami Shoten, 2005-2006). See also Matsuura Masataka, "Dai Tōa Sensō” wa naze okita no ka: han Ajia shugi no seiji keizaishi (Nagoya: Nagoya Daigaku Shuppankai, 2010).

88 Gavan McCormack, "Facing the Past: War and Historical Memory in Japan and Korea," AsiaPacific Journal 50, 4 (2008), at: http://www.japanfocus.org/-Gavan-McCormack/2983.
} 
stipulations that teachers and textbooks "acknowledge and recognize in particular the positive role of the French presence abroad, especially in North Africa"- dates back to the 1990s. That is when revisionist historians sought to instill a sense of pride in the nation and replace what they denounced as the "masochistic view of history" that had become hegemonic in the postwar decades. ${ }^{89}$ Here, too, textbooks were the preferred media, as nationalist intellectuals like Fujioka Nobukatsu and Nishio Kanji worked to inculcate the next generation of Japanese with the new nationalist gospel. Their writings sold millions of copies and reached a huge audience, easily exceeding those of the critical textbooks. ${ }^{90}$

Part of the appeal of the revisionists lay in their conventional valorization of the war. Prominent examples included the film "Pride," in which the role of General Tōjō Hideki, who was executed as a war criminal, received a favorable revaluation; and the commercially highly successful comic "On the War" (Sensōron), by the popular illustrator Kobayashi Yoshinori. ${ }^{91}$ But increasingly the focus has shifted to the former colonized territories, and a reassessment of Japan's contribution to the modernization of those subject nations. In these interpretations, Japanese colonialism emerges as a relatively benevolent and benign form of rule, with positive effects for the economic, infrastructural, social, and cultural development of the colonies. "On Taiwan" (Taiwanron 2000), another comic by Kobayashi Yoshinori, expressed this neo-nationalist orthodoxy and stirred protest upon release in Taiwan. It sold more than two hundred and fifty thousand copies in Japan. ${ }^{92}$ Like their opponents on the political left, nationalists have tried to insert, and in their case legitimate, the twentieth-century empire in a longer history of Japan in Asia. ${ }^{93}$

The history of empire, then, has returned and has been appropriated across the political spectrum by varied interests and with different implications. But though the memory of empire is now firmly entrenched in Japanese public and political debates, this has not been due to the work of Japanese actors alone. A second dimension of the return of empire that I want to briefly consider here is that, since the 1990s, the debate on memory in Japan has taken

${ }^{89}$ Fujioka Nobukatsu, Ojoku no kingendaishi (Tokyo: Tendensha, 1996).

${ }^{90}$ See, especially, Fujioka Nobukatsu, ed., Kyōkasho ga oshienai rekishi, 4 vols. (Tokyo: Tokuma Shoten, 1996-98); See also the vehement reactions to these approaches in: Kyōkasho ni shinjitsu to jiyū o' renrakukai, ed., Tettei hihan: 'Kokumin no rekishi' (Tokyo: Ōtsuki Shoten, 2000); Hiroshi Mitani, ed., Rekishi kyōkasho mondai (Tokyo: Nihon Tosho Sentâ, 2007).

${ }^{91}$ Kobayashi Yoshinori, Sensōron (Tokyo: Gentôsha, 1998). However, popular versions of the past are scarcely a new phenomenon.

92 Kobayashi Yoshinori, Taiwanron (Tokyo: Shôgakkan, 2000). On the debate, see Higashi Ajia Bunshitetsu Nettowāku, ed., Kobayashi Yoshinori Taiwanron o koete: Taiwan eno atarashii shiza (Tokyo: Sakuhinsha, 2001); Marukawa Tetsushi, "On Kobayashi Yoshinori's On Taiwan," Positions: East Asia Cultures Critique 12 (2004): 93-112.

${ }_{93}$ See, for example, Kawakatsu Heita, Nihon bunmei to kindai seiyo (Tokyo: NHK Books, 1991); Nishio Kanji, Kokumin no rekishi, Atarashii rekishi kyōkasho o tsukuru kai, ed. (Tokyo: Sankei Shinbunsha, 1999). 
on a decidedly transnational dimension. To be sure, this is not in itself a completely new phenomenon, and memory debates in any country never evolve in isolation. What has been new is the urgency with which actors from outside of Japan have intervened, and clamored for and eventually received a hearing within Japanese debates. Moreover, the composition of the voices that have gained a hearing in Japan shifted markedly. While positions and models from the United States and Europe - such as the Enola Gay controversy, the German-Polish textbook negotiations, and the 1985 speech of German President Richard von Weizsäcker-have continued to influence the Japanese public, what is noteworthy is the degree to which participants from other Asian countries, most of them non-state activists, have helped transform a Japanese preoccupation with Japan's national past into a transnational endeavor. ${ }^{94}$ In the 1990s, individuals and civil society groups from other Asian nations began to play leading roles in a shifting terrain of Japanese memory production. Through these various and sometimes discordant interventions, they contributed to the emergence of what Lisa Yoneyama has called "postnationalist public spheres in the production of historical knowledge." 95 The multiplication of actors and the discursive coalitions across national boundaries attest to both the centrality of memory politics in Japan today and the crucial role of empire/"Asia" in the context of contemporary Japanese debate. ${ }^{96}$

\section{CONCLUSION}

After long decades in which it resided in relative oblivion, Japan's imperial past finally returned to the public consciousness in the 1990s. But has it really returned? On the surface of things, the current obsession with the imperial legacy may appear as the "return of the repressed." As in many other postimperial countries such as France, the Netherlands, and Portugal, the memory of empire has reemerged after what some commentators, borrowing language from psychoanalysis, have described as forgetting, and "amnesia." There are indeed important continuities to consider, since some of the civil society groups that have campaigned since the early postwar years for recognition of Japanese victimization of other Asians have remained important players into the new millennium. Individual actors, such as journalist Honda

\footnotetext{
94 On the German model, see Awaya Kentarō, ed., Sensō sekinin-sengo sekinin: Nihon to Doitsu wa dō chigau ka (Tokyo: Asahi Shinbunsha, 1994); Satō Takeo, "Doitsu no sengo hoshō-Nihon no mohan ka," Sekai 561 (1991): 296-309; Nishio Kanji, Kotonaru higeki: Nihon to Doitsu (Tokyo: Bungei Shunjû, 1994).

95 Lisa Yoneyama, "Transformative Knowledge and Postnationalist Public Sphere: The Smithsonian Enola Gay Controversy," in Takashi Fujitani, Geoffrey M. White, and Lisa Yoneyama, eds., Perilous Memories: The Asia Pacific Wars (Durham: Duke University Press, 2001): 323-46.

96 See Norma Field, "War and Apology: Japan, Asia, the Fiftieth, and After," Positions: East Asia Cultures Critique 5, 1 (1997): 165-88; Gluck, "Operations of Memory."
} 
Katsuichi, have stayed at the forefront of political and legal battles over how to read the wartime and imperial past.

It is also clear that the upsurge in memory activity has had a generational element, at least partly. Those who had experienced the empire themselves and could still remember it knew they would not be around much longer. This biological factor has plainly contributed to the heated nature of some of the conflicts, especially when issues of monetary or symbolic compensation were at stake. In addition, there developed an urgent need to document and testify to personal experiences at a time when only a few witnesses were still alive. The extraordinary boom of personal histories (jibunshi) composed by innumerable "ordinary Japanese" is testimony to the generational dynamic at work. ${ }^{97}$

And yet, in many ways the exploding interest in issues of empire was not only a return; it was also a new departure, since continuities with a shared Asian past proved important but were soon subsumed within the dynamics set in motion by shifting geopolitical grounds. A crucial factor behind the boom of the trope of empire was the dissolution of the Cold War order, which opened up a new space for the articulation of claims on the past. In particular, the end of a regime that was essentially formatted according to the East-West dichotomy sparked a process that allowed political groups and civil society initiatives, and also corporate interests, to focus on East Asia as a region. Institutions of political cooperation began to emerge, and there was a marked increase in NGO actions on issues ranging from the environment and water management, to migration, to terrorism. At the same time, beginning from about the mid-1990s, East Asia increasingly became a region of intensive trade relations. In Japan, trade with the neighboring Asian countries surpassed economic exchange with the United States in 1993. Ironically, this was the same year that the Liberal Democratic Party, with its fixation on the United States, lost its long-held, dominant position in parliament. Most conspicuously, culture has emerged as a crucial site for integration in East Asia, including ideological claims to cultural commonalities such as Confucianism and the so-called "Asian values," and material forms of exchange of a popular culture that is increasingly consumed transnationally. ${ }^{98}$

\footnotetext{
${ }^{97}$ See Petra Buchholz, Schreiben und Erinnern: Über den Umgang mit der Vergangenheit in Japan (München: Iudicium, 2002); Gerald Figal, "How to Jibunshi: Making and Marketing SelfHistories of Shōwa among the Masses in Postwar Japan," Journal of Asian Studies 55 (1996): 902-33.

98 On regionalism in East Asia, see T. J. Pempel, ed., Remapping East Asia: The Construction of a Region (Ithaca: Cornell University Press, 2004); Peter J. Katzenstein and Takashi Shiraishi, eds., Beyond Japan: The Dynamics of East Asian Regionalism (Ithaca: Cornell University Press, 2006). For an analysis of 1990s Japan, see also Tomiko Yoda and Harry D. Harootunian, eds., Japan after Japan: Social and Cultural Life from the Recessionary 1990s to the Present (Durham: Duke University Press, 2006); Richard J. Samuels, Securing Japan: Tokyo 's Grand Strategy and the Future of East Asia (Ithaca: Cornell University Press, 2007).
} 
This broader process of regionalization as one feature of the globalized, post-Cold War order had important repercussions in the field of memory. It shifted the parameters of public debate, enabled new discursive and political coalitions to emerge, and palpably turned interpretations of the imperial past into a privileged arena within which possibilities of Asian exchange and cooperation were negotiated. This was, then, not primarily a return of empire, but the arrival of Asia, conditioned by global geopolitical transformations and new structures of global capitalism. ${ }^{99}$ At this juncture, the memory of Japanese colonialism became one of the currencies of exchange that made integration possible, and rendered different national trajectories compatible. Consequently, some observers disapproved of Prime Minister Koizumi's controversial visits to Yasukuni Shrine not so much for their nationalist overtones and distorted view of the past, but rather because of fears that they would present an obstacle to Japanese access to Asian markets. The public concerns with Asia and empire in post-1990s Japan must be situated within this context of emerging regionalism and regionalist agendas, not only in East Asia but across the globe.

\begin{abstract}
Between 1895 and 1945 Japan assembled one of the largest empires in modern world history. It vanished abruptly in the summer of 1945 at the end of the Second World War, and seemed to leave no trace in public consciousness. Historians, too, have portrayed postwar Japan as characterized by a virtual erasure of the imperial past. This article draws on recent scholarship to argue that things were more complicated than that. While references to the imperial past indeed dwindled after about 1960, immediate forgetting did not exhaust the reactions by individuals and interest groups. Some social milieus experienced the dissolution of the empire much more profoundly than official discourse would suggest. Since the mid-1990s, Japan's imperial past has reemerged as a major field of historical inquiry and a more general concern in public debate. In this article I situate the dialectic of remembering and forgetting within larger processes and transformations of the postwar order in East Asia, in particular the American occupation and the emergence of the Cold War.
\end{abstract}

\footnotetext{
${ }^{99}$ Leo Ching, "Globalizing the Regional, Regionalizing the Global: Mass Culture and Asianism in the Age of Late Capital," Public Culture 12 (2000): 233-57.
} 